\title{
Gender Differences in Entrepreneurial Attitudes and Constraints: Do the Constraints Predict University Agriculture Graduates' Attitudes towards Entrepreneurship?
}

\author{
Som Pal Baliyan ${ }^{1}$, Paseka Andrew Mosia ${ }^{2}$, Pritika Singh Baliyan ${ }^{3}$ \\ ${ }^{1}$ Botswana University of Agriculture and Natural Resources, Botswana \\ ${ }^{2}$ National University of Lesotho, Lesotho \\ ${ }^{3}$ University of Botswana, Botswana \\ Correspondence: Som Pal Baliyan, Botswana University of Agriculture and Natural Resources, Botswana. Email: \\ baliyansom@gmail.com.
}

Received: June 20, 2020

Accepted: August 3, 2020

Online Published: August 5, 2020

doi:10.5430/ijhe.v9n5p259

URL: https://doi.org/10.5430/ijhe.v9n5p259

\begin{abstract}
This quantitative study analyzed and predicted gender differences of agriculture graduates' attitudes towards and challenges in entrepreneurship in Botswana. The study adopted a descriptive and correlational survey research design. A valid and reliable questionnaire was used for data collection through a survey of randomly sampled 149 final year agriculture graduate students $(\mathrm{n}=149)$. Inferential statistical tools of Independent $\mathrm{t}$-test and Regression analysis were used for data analysis. The findings of the study determined three important attitudinal factors as: entrepreneurship results in economic growth of a country, employability and income generation and, entrepreneurship improves individual and social growth. Three important constraints in entrepreneurship were lack of land, lack of proper infrastructure and, lack of capital. These top attitudinal factors as well as constraints were the same for the male and female graduates despite of their ranking and importance. A gender difference in students' attitudes towards entrepreneurship was established while no gender difference in the challenges in entrepreneurship was found. Out of fifteen constraints in entrepreneurship under study, only three constraints namely, lack of land, high competition in market and lack of capital, were determined as significant predictors of the graduates' attitudes towards entrepreneurship. It is recommended that these three factors be made priorities while making policies for entrepreneurship development in the country. Further study is recommended to explore the perceptions of graduates on the possible ways to improve on these three predicting constraints and explore latent constraints predicting graduates' attitude towards entrepreneurship. Those findings may provide better ideas in planning policies for entrepreneurial development among agriculture graduates in Botswana.
\end{abstract}

Keywords: agriculture entrepreneurship, agriculture graduates, Botswana, entrepreneurial attitude, entrepreneurial constraints, gender differences

\section{Introduction}

Most of African countries are at an early stage of economic development and, there are several socio-economic, political and environmental constraints responsible for that (Kew, 2015; Santos et al., 2016). Entrepreneurship has been considered a driver to economic growth and development worldwide (Audretsch \& Belitski, 2017) and, there has also been a gradual change in the entrepreneurial development in Africa to counter the global economic, political and, technological changes (Jones et al., 2018). Recognizing the importance of entrepreneurship in creating jobs and self-employment, governments and policymakers worldwide, particularly in Africa, have encouraged graduates not to depend on employment, rather to start their own businesses as a pathway to create jobs and contribute to socio-economic development. Botswana has emphasized self-employment through entrepreneurship as a basic solution to growing unemployment challenges (Hoskin Pour \& Rzai, 2010). Rapid growth of entrepreneurship globally is attributed to the power of education in promoting socioeconomic well-being of an individual and countries as well. Higher education institutions (HEIs) play an important role in providing education and training to potential entrepreneurs (Farashah 2013; Lanero, Vázquez, Gutiérrez, \& García, 2011) as well as providing a platform for students to be successful entrepreneurs in the future (Kozina \& Ponikvar, 2015; Jelonek, Dunay, Alint, \& Csaba, 2017) and thus, promoting entrepreneurship to develop economy of a country (Dembek, Singh, \& Bhakoo, 2016; van 
der Have \& Rubalcaba, 2016). Consequently, Botswana has put intensive efforts and programmes towards development of entrepreneurship assisting graduates to be entrepreneurs in order to create jobs for others. Entrepreneurial development programmes are offered at all levels of the education system in Botswana as part of the curriculum to equip students with entrepreneurial skills. The Botswana University of Agriculture and Natural Resources offers agricultural education programmes from certificate to degree levels integrated with entrepreneurship knowledge to develop agricultural entrepreneurs.

Botswana, as most of the other middle-income countries in southern Africa, has been among the slow growing economies grappling with high unemployment, especially youth unemployment which has remained elusive (Jauch 2011; Ncube, Shimeles, \& Verdier-Chouchane, 2014). Although the country promotes entrepreneurship, the labour market is characterized by high and increasing unemployment rate which has consistently been a 2-digit figure averaging 18.2\% between 2000 and 2016 (Morima, 2012; Matandare, 2018). Unemployment rates in the country have been rising from as low as 10.2 percent in 1981 to as high as 25.3 percent in 1984 (Malema, 2011). It hit an all-time high record of 26.2\% in 2008 (World Bank, 2017). Most of the unemployed in Botswana are relatively young people (World Bank, 2015). Illustratively, du Toit and Gaotlhobogwe (2018) state that youth unemployment was estimated to be 34 percent in 2016 and this was 14 percent higher than the national unemployment rate. Thus, youth unemployment in Botswana exceeds the national unemployment (Morima, 2012; Bogale, 2014). Further, female unemployment rate is higher than male unemployment rate (Matandare, 2018). The root cause for this level of unemployment is a failure to create enough jobs in the economy the country has failed to translate high economic growth to job creation (Diraditsile \& Ontetse, 2017). This is evidenced by the fact that Botswana is still ranked the lowest in terms of entrepreneurial development among all developing countries in Africa (World Economic Forum, 2016; Abubakar, 2015). The Global Entrepreneurship Index (GEI) (2015) scored and ranked Botswana as 36.4 and 53, respectively whereas South Africa ranked 36 with a score of 42.2 GEI, and USA ranks the highest in the world with 82.9 (Terjesen \& Lloyd, 2015). Higher GEI rank of South Africa and USA indicates that these countries do better in entrepreneurship than Botswana. Poor attitude and lack of entrepreneurship culture among youth and particularly graduates can be one of the reasons for unemployment in Botswana.

Considering the growing role of entrepreneurship as a decisive factor for socio-economic development (Engle et al., 2010), researchers have started to focus their attention on understanding and predicting entrepreneurial attitudes (Vamvaka, Stoforos, \& Palaskas, 2020). Several factors may have contributed to the poor entrepreneurship culture among youth in the country, including gender of entrepreneurs, attitude towards entrepreneurship, constraints in entrepreneurship. It is important to study personal attitudes because human behaviour is one of the major components influencing decisions about the act and conduct (Akbari, Movahedi, \& Kochekian, 2010). Thus, understanding attitudes towards and constraints in entrepreneurship can be instrumental in formulation of policy to encourage entrepreneurship (Bosma \& Levie, 2009). An investigation of graduates' attitudes towards entrepreneurship is important because these attitudes and constraints may reflect the prospect of becoming entrepreneurs (Guerrero, Rialp, \& Urbano, 2008).

\subsection{Problem Statement}

Considering the importance of entrepreneurship in its socio-economic development spectrum, Botswana government initiated rigorous efforts and programmes encouraging youth to venture into wealth creation, economic growth and sustainable jobs through entrepreneurial development, but did bear poor fruit contrary to what was expected and, constant rise in unemployment among youths. Entrepreneurial development among graduates may be influenced by various factors including the attitude of the potential entrepreneurs towards entrepreneurship and, constraints they face in entrepreneurship. A better understanding of the attitudes and constraints in entrepreneurship in Botswana may help to evaluate, reinforce and change strategies to enhance prevailing entrepreneurial situation among youths, particularly graduates in the country. Therefore, this study aims to analyze the attitudes and constraints among male and female graduates towards entrepreneurship in Botswana.

\subsection{Aim and Objectives of the Study}

The aim of the study is to analyse the gender differences among agriculture graduates' attitudes towards and constraints in entrepreneurship. The specific objectives of this study are:

i) To determine gender difference among agriculture graduates in their attitudes towards entrepreneurship.

ii) To determine gender difference among agriculture graduates in the challenges in entrepreneurship.

iii) To determine the constraints in entrepreneurship as predictors of graduates' attitudes towards entrepreneurship.

The objectives of the study were translated into the following research questions: 
i) Is there any significant difference in attitudes towards entrepreneurship between male and female graduates?

ii) Is there any significant difference in challenges in entrepreneurship between male and female graduates?

iii) Do constraints in entrepreneurship significantly predict graduates' attitudes towards entrepreneurship?

To answer the research questions, the following null hypotheses were formulated and tested.

i) There is no significant difference in attitudes towards entrepreneurship between male and female graduates.

ii) There is no significant difference in challenges in entrepreneurship between male and female graduates.

iii) The constraints in entrepreneurship do not significantly predict graduates' attitudes towards entrepreneurship.

The findings of the study may provide useful information to help policymakers to formulate the policies for promoting entrepreneurship and self-employment which may reduce the burden of unemployment, among the graduates, particularly agriculture graduates. Moreover, it may contribute to the literature of entrepreneurship, for Botswana and other developing countries.

\section{Review of Literature}

\subsection{Entrepreneurship and its Importance}

In the context of understanding the role of entrepreneurship in economic growth, the Global Entrepreneurship Monitor (GEM), (2014, p.17) defines entrepreneurship as "any attempt at new business or new venture creation, such as self-employment, a new business organization, or the expansion of an existing business, by an individual, a team of individuals, or an established business." Entrepreneurship is more than owning or starting a business but "a process through which individuals identify opportunities, allocate resources, and create value" (Akinyoade, Dietz, \& Uche, 2017, p.1). It is also known as an act of making innovations and financing them "in an effort to transform innovations into economic goods" (Stafford \& Hartman, 2014, p.164). Thus, an entrepreneur sees problems as opportunities, and then takes necessary action to solve them.

There is abundant literature reflecting the importance of entrepreneurship. Being the vehicle for social development since the fifteenth century (Schumpeter, 1912; Kirchhoff, Linton, \& Walsh, 2013) the impact of entrepreneurship in the economy worldwide cannot be overemphasized (Glinskiene \& Petuskiene, 2011). Entrepreneurship, launched as an important instrument for social cohesion, is regarded as one of the best tools to boost socio-economic growth and stability of countries (Kidane \& Harvey, 2009; Nafukko \& Muyia, 2010; Raman, Anantharaman, \& Ramanathan, 2013). It is an important driver of economic progress, job creation and social adjustment and, to reduce unemployment (G20, 2014; Nybakk \& Hansen, 2008; Teixeira \& Davey, 2008; Movahedi, Latifi, \& Sayyar, 2013). Unemployment, especially among the youth, has been one of the major challenges in global transition (Brixiova, Ncube, \& Bicaba, 2015; AERC, 2014). With the limited role of governments in job creation, promoting entrepreneurship has become one of the policy options for nations to sustain growth and create more jobs to curb unemployment (Global Entrepreneurship Monitor GEN, 2013; Ibrahim, Devesh, \& Ubaidullah, 2017). Entrepreneurship for job creation has been documented as one of the important remedies for Africa's growing population and, thus, reducing unemployment and poverty (Tchamyou, 2016). Unemployment among youth in Africa, especially Sub-Saharan Africa, has remained high (Jauch, 2011; Ncube et al., 2014) thus compelling unemployed youth to venture into self-employment in the informal sector (Chigunta, 2017). Therefore, entrepreneurship is increasingly becoming important around the world (Movahedi, Fathi, \& Brijal, 2011) and is particularly true in emerging economies where unemployment levels are high.

\subsection{Entrepreneurial Attitude and Gender}

Entrepreneurship is a multifaceted endeavor that is affected by a variety of demographic, social, cultural, economic and, environmental factors (Arranz, Arroyabe, \& Fdez. de Arroyabe, 2019). Attitudes are predispositions for one to respond in a generally favourable or unfavourable manner with respect to an object (Ajzen, 1991) and they are vital for successful entrepreneurship. Krech and Crutchfield (1948 in Fishbein \& Raven, 1962, p.40) define attitude as "an enduring organization of motivational, emotional and perceptual and cognitive processes with respect to some aspect of the individual's world". It is an evaluative aspect of a person's thinking which determines whether an issue is good or bad (Fishbein \& Raven, 1962). Kleinke (1984) conceptualizes attitudes as resulting from past experiences and argues that 'persuasive communication' or external influence plays a role in modeling attitudes and behaviour. In this regard, entrepreneurship attitudes vary from one individual to another depending on factors influencing the career (Global Entrepreneurship Monitor Report, GEM, 2009). Guerrero, Rialp and Urbano (2008) state that attitudes towards entrepreneurship result from individuals' immediate beliefs as affected by various individual, social, cultural, environmental and ecological factors (Benoit \& Narjisse, 2006). Socioeconomic factors like gender, 
parental qualification and profession and family income received considerable attention (Schroeder \& Rodermund, 2006; Zampetakis \& Moustakis, 2006; Ali, Keith, Topping, \& Tariq, 2011; Movahedi, et al., 2013) in determining attitude towards entrepreneurship.

Literature on entrepreneurship has indicated the role of gender in the formation of entrepreneurial attitude (Vamvaka, Stoforos, \& Palaskas, 2020). Gender has been found as one of the important factors influencing entrepreneurship worldwide (Nowiński, Haddoud, Lančarič, Egerová, \& Czeglédi, 2019). Several studies has been conducted on gender and its relationship with entrepreneurship in several countries; Greece (Vlachos, 2016), OECD countries (Millán, Congregado, \& Román, 2014), United Kingdom (Dawson, Henley, \& Latreille, 2009), Portugal (Macieira, 2009), various developing countries (Pietrobelli, Rabellotti, \& Aquilina, 2004) and, Botswana (Almqvist \& Bjornberg, 2010). Thus, understanding gender differences has been a major focus in the entrepreneurship literature. Entrepreneurship is traditionally viewed as male dominated and thus, majority of entrepreneurs are male (Almqvist \& Bjornberg, 2010; Vamvaka, Stoforos, \& Palaskas, 2020). Fragoso, Rocha-Junior and Xavier (2019) reported that men have higher entrepreneurial intentions than women. Several studies suggest that males have a higher preference and willingness for entrepreneurship than females (Delmar \& Davidsson, 2000; Díaz-García and Jiménez-Moreno 2010; Verheul, Thurik, Grilo, \& van der Zwan, 2012; Zellweger, Sieger, \& Halter, 2011; Vlachos, 2016; Nikolova \& Bargar, 2010).

While many countries have attained gender parity in educational outcomes, disparities in accessing economic and political opportunities continue between the genders with females having less property rights (Bandiera \& Natraj, 2013). Bandiera and Natraj (2013) argue that constraints on these rights impair women's economic outlook and efficiency. Basically, the need to inspire women into the entrepreneurship career must be coupled with transforming bias labour and property laws that result from patriarchal institutional arrangements (Cuberes \& Teignier-Baque, 2011; Ahang, 2014) leaving them disproportionately vulnerable to poverty and starvation (Mukherjee \& Mukhopadhyay, 2013). Thus, women's attitudes towards entrepreneurship could reflect the conflict between 'perceived desirability' and 'perceived feasibility' borne by their context (Pauceanu, Alpenidze, Edu, \& Zaharia, 2019). Despite the increased participation of females in entrepreneurial activities, male entrepreneurs are still dominant (Shirokova, Osiyevskyy, \& Bogatyreva, 2016; Zampetakis, Bakatsaki, Litos, Kafetsios, \& Moustakis, 2017). Despite contextual challenges noted above, some studies report that females have a higher preference for entrepreneurship (Sohl, 2014; Brush et al., 2014; Gaetsewe, 2018). On the other hand, some studies suggest there is no gender difference in entrepreneurship and, conclude that the students' perception towards entrepreneurship is gender neutral (Obembe, Otesile, \& Ukpong, 2014; Lerog \& Sels, 2014; Nowinski, Haddard, 2019; Shirokova et al., 2016; Sitaridis, 2019). Further, Haus et al., (2013) and Egerove and Ozegledi, (2019) found a weak effect of gender on entrepreneurship and, these are contradictory with the findings of Sheroer and Jenson (2014) who conducted a meta-analysis and found that gender has an effect on entrepreneurship. Thus, the findings on gender difference in attitudes towards entrepreneurship remain inconclusive.

\subsection{Entrepreneurial Constraints and Gender}

Entrepreneurial development in Africa is faced with a number of constraints hampering its success such as access to finance, access to market, policy support and entrepreneurship culture (Abubakar, 2015). Chinomona, and Mazariri, (2015) echo the same sentiments of lack of access to finance expressed by Abubakar. Poor infrastructure, inaccessibility to international markets (Bowen, Morara \& Mureithi, 2009; Abor \& Quartey, 2010), lack of access to finance and inadequate government support (Tandei Chamula, \& fortunate, 2015), lack of resources (Chua, Chrisman, Kellermanns \& Wu, 2011; Elizabeth Chinomona, \& Eugine Mazariri, 2015) are highlighted as constraints towards entrepreneurship. A very few studies have reported entrepreneurial constraints in Botswana. Mutoko, (2014) reported lack of access to markets, poor work ethics, lack of funding and, lack of management skills and training as main challenges in entrepreneurship. Finance is regarded as 'life blood' for any enterprise and, is one of the major obstacles which women face in setting up their enterprises (Wasilczuk \& Zieba, 2008; Phillips, Moos \& Nieman, 2014). According to Mannathoko (2011), many small enterprises in Botswana do not survive more than 3 years; $80 \%$ of them fail within the first 3 years of operation.

Focusing on the literature on entrepreneurial constraints in the context of other African countries, Staniewski and Awruk (2015) determine factors that hamper potential entrepreneurs in starting up their own businesses and, report lack of capital/funds as the main factor hampering the commencement of a business. It has been suggested that institutions handling financial aid should pay particular attention and, should be preceded by an in-depth analysis of the barriers of lack of funds perceived to starting own business. Arranz, Arroyabe, and Fdez de Arroyabe (2019) studied entrepreneurial intentions in undergraduate students and the obstacles perceived by the undergraduate 
university students towards entrepreneurship. They argue that financial obstacles were among the main barriers students perceive to starting their own businesses. Mahadea and Khumalo (2020) investigated the constraints in the development of micro ventures in South Africa and, found that almost two-thirds of the total variation in growth limitations of enterprises is with integrated component of sale (market), asset, labour and storage and infrastructure. Fall (2020) studied the constraints that inhibit growth and investment in enterprises in Gambia and through a critical literature review, and, established the impeding factors including lack of access to credit, lack of access to market and limited access to business development services. Further, it emphasised the need to provide easy access to finance, market and business development services. Amungo (2020) reported that the business climate and lack of finance remains major suppressants of growth of enterprises in Africa suggested that the efforts need to be intensified to expand access to capital, improve business climate to sustain the entrepreneurial growth in Africa. Further, Nwajiuba, Igwe, Binuomote, Nwajiuba, and Nwekpa (2020) examined the challenges faced by the small and medium enterprises in African entrepreneurial system and, determined major challenges among others as lack of finance, lack of innovation and technology, low skilled workforce, and poor infrastructure. These challenges have implications on unemployment and poverty rates as well as economic growth in Africa. The literature reported several constraints in entrepreneurial development in some of the African countries. However, not much such literature has focused in the context of Botswana particularly, on gender difference on entrepreneurship.

\section{Methodology}

A descriptive and co-relational research design was adopted in this quantitative study. The population consisted of final year undergraduate students at the Botswana University of Agriculture and Natural Resources, Gaborone, Botswana. A total of 149 undergraduate students $(n=149)$ enrolled in agricultural programmes were randomly sampled. A valid and reliable questionnaire was constructed for data collection. The first part of the questionnaire was designed to obtain information on the gender of the students. The second part of the instrument composed of twelve (12) items measuring the students' attitudes towards entrepreneurship. The third part of the instrument composed of fifteen (15) items measuring the constraints in the entrepreneurial development. The items on attitudes and constraints were measured on a four-point Likert's scale: Strongly Agree (SA) $=4$, Agree (A) $=3$, Disagree (D) $=2$ and Strongly Disagree $(\mathrm{SD})=1$. Likert scale is one of the most frequently used psychometric tools in educational and social sciences research (Joshi, Kale, Chandel, \& Pal, 2015). The instrument was validated for its content and face validity by a panel of experts in the area of agricultural education and entrepreneurship. The reliability analysis was conducted to determine the reliability of the questionnaire. Cronbach's alpha reliability coefficient of the students' attitudes towards entrepreneurship and, constraints in entrepreneurship were determined to be .812 and .715 , respectively. Thus, the instrument was reliable as the reliability coefficients were greater than the minimum expected level of .70 (Creswell \& Creswell, 2017).

Data were collected through survey using the valid and reliable questionnaire. Data were analysed using the SPSS Software Version 23 whereby inferential statistical tools of Independent t-test and Multiple regression analysis were employed. An Independent t-test was employed to determine the gender difference in the graduates' attitudes towards entrepreneurship and, constraints in entrepreneurial development whereby gender of the students was used as an independent variable and, the students' attitude was treated as a dependent variable. An Independent t-test was also employed to determine gender difference among agriculture graduates in the challenges in entrepreneurship whereby gender of the graduates was used as an independent variable and, the constraints in entrepreneurship was treated as a dependent variable. A stepwise multiple regression analysis was used to predict the students' attitudes towards entrepreneurship. For regression analyses, the score of students' attitudes towards entrepreneurship and, the score of constraints in entrepreneurship were considered as dependent variables and independent variables, respectively.

\section{Results and Discussion}

\subsection{Gender Difference in Students' Attitudes towards Entrepreneurship}

The first objective of this study was to determine gender difference among agriculture graduates in their attitudes towards entrepreneurship. An Independent $t$-test was employed to achieve this objective. The results of the Independent t-test are presented in Table 1. Table 1 shows a significant gender difference on students' attitudes towards entrepreneurship $(\mathrm{t}=-4.065, \mathrm{p}=.000)$. Further, female students have higher significant influence on the attitudes towards entrepreneurship $(\overline{\mathrm{x}}=31.92)$ as compared to the influence of male students $(\overline{\mathrm{x}}=28.21)$. This finding compares with Gaetsewe's (2018) study that found that females have a higher preference for entrepreneurship. Contradictorily, majority of studies have suggested that males have a higher preference for entrepreneurship than females (Delmar \& Davidson, 2000; Díaz-García and Jiménez-Moreno, 2010; Verheul et al., 
2012; Zellweger et al., 2011, Vlachos, 2016; Millan et al., 2014; Nikolova \& Bargar, 2010; Sohl, 2014; Brush, Edelman, Manolova, \& Welter, 2019). These findings may imply that women are forced into self-employment as they have limited opportunities for getting employment. Moreover, women in Botswana push themselves in order to make their lives self-dependent, implying that they would be more likely to engage in self-employment than men (Almqvist \& Bjornberg, 2010).

Table 1. Independent t-test of the influence of graduates' gender on attitude towards entrepreneurship

$\begin{array}{lllllll}\text { Variable } & \text { Level } & \mathrm{n} & \overline{\mathrm{x}} & \mathrm{SD} & \mathrm{t} \text {-value } & p .\end{array}$

\begin{tabular}{lllllllll} 
Attitude & Male & 48 & 28.21 & 2.67 & .38 & & \\
& Female & 101 & 31.92 & 6.04 & .60 & $-4.065^{*}$ & .000 \\
\hline
\end{tabular}

$p<.05$

There were 12 items (factors) measuring the graduates' attitudes towards entrepreneurship. In order to determine the item wise gender difference in the attitude, an independent test was run and, the findings are presented in Table 2.

Table 2. T-test statistics of graduates' gender and their attitude towards entrepreneurship

\begin{tabular}{|c|c|c|c|c|c|}
\hline \multirow[t]{2}{*}{ Attitude towards entrepreneurship } & \multicolumn{2}{|l|}{ Male } & \multicolumn{3}{|c|}{ Female } \\
\hline & $\overline{\mathrm{x}}$ & $\mathrm{SD}$ & $\overline{\mathrm{x}}$ & $\mathrm{SD}$ & $p$ \\
\hline Improves individual and social growth & 3.54 & .50 & 3.22 & .92 & .025 \\
\hline Vital to achieve each degree program & 2.87 & .84 & 3.15 & .78 & .053 \\
\hline Boost economic growth of a country & 3.67 & .60 & 3.31 & .88 & .011 \\
\hline Improves employment and income & 3.56 & .65 & 3.77 & .51 & .033 \\
\hline Has a bright future in Botswana & 3.23 & .75 & 3.29 & .75 & .661 \\
\hline Useful to the society & 3.35 & .63 & 3.27 & .77 & .500 \\
\hline Has no status in Botswana & 1.62 & .78 & 1.60 & .75 & .875 \\
\hline Unnecessary for growth and development & 1.29 & .58 & 2.02 & 1.17 & .000 \\
\hline Not important for life & 1.27 & .44 & 2.01 & 1.28 & .000 \\
\hline Wastage of time & 1.29 & .58 & 2.05 & 1.33 & .000 \\
\hline Degrades the individual social status & 1.23 & .42 & 2.13 & 1.33 & .000 \\
\hline Do not help in business development & 1.27 & .45 & 2.07 & 1.32 & .000 \\
\hline
\end{tabular}


Table 2 shows that the three top attitudinal factors which contributed significantly to the difference in the attitude of male students are entrepreneurship results in economic growth of a country $(\bar{x}=3.67)$, entrepreneurship results in employability and income generation $(\bar{x}=3.56)$, and, entrepreneurship improves of individual and social growth $(\bar{x}=$ 3.54). In the case of female graduates, the top three attitudinal factors which contributed significantly to the difference are entrepreneurship results in employability and income generation $(\bar{x}=3.77)$, entrepreneurship results in economic growth of a country $(\overline{\mathrm{x}}=3.31)$ and, entrepreneurship improves of individual and social growth $(\overline{\mathrm{x}}=3.22)$. The different priorities in male and female outlooks may result from practical life challenges where in Botswana, as in many other developing countries, women sustain families and may prioritise family sustenance ahead of national development. Bandiera and Natraj (2013) note that social constraints impair women's economic outlook and efficiency. These findings suggest that the top three attitudinal factors in entrepreneurship for male and female graduates are the same with the difference in their ranking and importance. This further indicates that these three factors should be priorities by the policy makers while making policies for entrepreneurial development in the country.

\subsection{Gender Difference in Constraints in Entrepreneurship}

The second objective of this study was to determine gender difference among graduates in the challenges in entrepreneurship. An Independent t-test was employed to achieve this objective. The results of the Independent t-test are presented in Table 3. Table 3 shows that there is no significant gender difference in the challenges in entrepreneurship $(\mathrm{t}=-1.170, \mathrm{p}=.260)$. It indicates that male and female graduates face the same constraints in entrepreneurship. However, female students had higher influence of constraints in the challenges in entrepreneurship $(\bar{x}=43.86)$ as compared to the influence of male students $(\bar{x}=42.73)$.

Table 3. Independent t-test of graduates' gender and constraints in entrepreneurship

$\begin{array}{lllllll}\text { Variable } & \text { Level } & \mathrm{n} & \overline{\mathrm{x}} & \mathrm{SD} & \mathrm{t} \text {-value } & p \text {. }\end{array}$

$\begin{array}{lllllllll}\text { Constraints } & \text { Male } & 48 & 42.73 & 5.33 & .76 & & \\ & \text { Female } & 101 & 43.86 & 5.89 & .58 & -1.170 & .260\end{array}$

There were 15 items (factors) measuring the constraints in entrepreneurship. In order to determine the item wise gender difference in these constraints, an Independent t-test was run and, the findings are presented in Table 4.

Table 4. T-test statistics of students' gender and challenges in entrepreneurship

\begin{tabular}{|c|c|c|c|c|c|}
\hline \multirow[t]{2}{*}{ Constraints in entrepreneurship } & \multicolumn{2}{|l|}{ Male } & \multicolumn{3}{|c|}{ Female } \\
\hline & $\overline{\mathrm{x}}$ & $\mathrm{SD}$ & $\overline{\mathrm{x}}$ & SD & $p$. \\
\hline Lack of land & 3.58 & .54 & 3.64 & 1.14 & .000 \\
\hline Lack of capital & 3.52 & .65 & 3.26 & .74 & .037 \\
\hline Lack of proper infrastructure & 3.21 & .82 & 3.41 & .65 & .115 \\
\hline Insufficient market/small population & 3.08 & .79 & 3.30 & .67 & .090 \\
\hline Poor work ethic & 3.06 & .78 & 3.12 & .74 & .670 \\
\hline Poor business practices & 3.08 & .79 & 3.20 & .73 & .387 \\
\hline
\end{tabular}




$\begin{array}{lccccc}\text { High competition in market } & 2.60 & .92 & 2.85 & .87 & .115 \\ \text { Insufficient entrepreneurial knowledge } & 3.06 & .78 & 3.12 & .85 & .749 \\ \text { Lack of government support } & 2.29 & .87 & 2.75 & .95 & .005 \\ \text { Contradictory government policies } & 2.60 & .79 & 2.64 & .90 & .796 \\ \text { Government bureaucracy } & 2.42 & .82 & 2.77 & .83 & .016 \\ \text { Restrictive labor regulations } & 2.40 & .84 & 2.58 & .80 & .190 \\ \text { Discouraging tax regulations } & & & & & .80 \\ \text { Government restrictions/policy } & 2.60 & .98 & 2.67 & .88 & .668 \\ \text { High crime and theft } & 2.40 & .84 & 2.64 & .80 & .017\end{array}$

Table 4 indicates that the top three factors which contributed significantly to the difference in the constraints for male graduates are lack of land $(\overline{\mathrm{x}}=3.58)$, lack of capital $(\overline{\mathrm{x}}=3.52)$ and, lack of proper infrastructure $(\overline{\mathrm{x}}=3.21)$. In the case of female graduates, the top three factors which contributed significantly to the difference in the attitude of female are lack of land $(\overline{\mathrm{x}}=3.64)$, lack of proper infrastructure $(\overline{\mathrm{x}}=3.41)$ and lack of capital $(\overline{\mathrm{x}}=3.26)$. These findings suggest that the top three constraints in entrepreneurship for male and female graduates are the same with the difference in their ranking and importance. The same constraints in entrepreneurship were also reported by various studies as the main problems and constraints on entrepreneurship development. As a necessary component for enterprises, lack of land was also identified as a constraint in entrepreneurship development by several researchers (Haselip, Desgain, \& Mackenzie, 2015; Mayer, Meyer, \& Molefe, 2016; Jaisawal \& Patel, 2016; Tambunan, 2017). Several researchers such as Mutoko (2014); Tandei Chamula and Fortunate (2015); Abubakar (2015); Esiobu and Ibe (2015) and; Tambunan (2017) reported lack of funds/capital. Poor infrastructure was reported as the main constraint in entrepreneurship among youths by Legas (2015); Rivera-Santos, Holt, Littlewood \& Kolk (2015); Jelilov and Onder (2016); Demiral, (2016); Igwa, Ogundana, Egere, \& Anigbo (2018), Shantz, Kistruck, \& Zietsma (2018) and, Nwajiuba, Igwe, Binuomote, Nwajiuba, \& Nwekpa, (2020). Unlike most literature which see females as having less property and political rights (Ahang, 2014; Bandiera \& Natraj, 2013; Cuberes \& Teignier-Baque, 2011), these findings suggest that both males and females feel that accessing land for entrepreneurial purposes would be the toughest hurdle.

\subsection{Prediction of Students' Attitudes from the Constraints in Entrepreneurship}

The third objective of the study was to predict graduates' attitudes towards entrepreneurship from the constraints in entrepreneurship. A Stepwise method of multiple regression analysis was used to answer this objective. Table 5 presents the results of the multiple regression analysis which indicates that the constraints in entrepreneurship are significant predictors of graduates' attitudes towards entrepreneurship $[\mathrm{F}(3,133)=35.81, \mathrm{p}=<.001)]$. 
Table 5. Stepwise Regression Analysis of constraints in entrepreneurship as predictors of graduates' attitude of towards entrepreneurship

\begin{tabular}{llllll}
\hline Source & SS & df & MS & F & p \\
\hline Regression & 1888.64 & 3 & 629.54 & 35.81 & .000 \\
Residual & 2549.07 & 133 & 17.58 & & \\
Total & 4437.71 & 148 & & & \\
\hline
\end{tabular}

Table 6 presents the regression coefficients reflecting the relative importance of the constraints in entrepreneurship factors in predicting the graduates' attitudes towards entrepreneurship. It highlights that only three constraints; lack of land, high competition in market and, lack of capital significantly predict graduates' attitude towards entrepreneurship. The total variance of prediction of graduates' attitudes towards entrepreneurship explained by the three predicting constraints contribute to 43 percent of the variance in graduates' attitudes towards entrepreneurship. It further explains that there are some other latent constraints responsible for the reaming variance of 57 percent to the graduates' attitude towards entrepreneurship. A further similar study can be conducted to explore more constraints predicting graduates' attitude towards entrepreneurship.

Table 6. Regression Coefficients of the constraints in entrepreneurship as predictors of graduates' attitude of towards entrepreneurship

\begin{tabular}{|c|c|c|c|c|}
\hline Predictors & $\mathrm{B}$ & Beta & t-value & $\mathrm{p}$ \\
\hline Constant & 32.035 & --- & 15.59 & .000 \\
\hline Lack of land & -3.018 & -.597 & -9.138 & .000 \\
\hline High competition in market & 1.331 & .217 & 3.407 & .001 \\
\hline Lack of capital & 1.168 & .154 & 2.383 & .018 \\
\hline
\end{tabular}

The findings of this study (Table 6) are similar to the findings reported by several other researchers. Ramawati, and Rohman (2020) and, Staniewski and Awruk, (2015) reported that the availability of financial capital is an important factor as it provides motivation to start a new enterprise. Brixiová, Kangoye, and Tregenna, (2020) find that land ownership is crucial for better performance of female entrepreneurs in Africa and, it was suggested that the Southern African economies would benefit if land tenure and financial institutions favour female entrepreneurs. Nwokorie, Edwin Chigozie, Adiukwu and Ikenna Kingsley (2020) also reveal that poor access to funds, inconsistent government policies and poor infrastructure affect productivity and sustainability of enterprises. In the case of Botswana, the inconsistent government policies such as import policies are responsible for high competitive markets in the country and hardly protect the local entrepreneurs; consequently, the local enterprises suffer losses and, ultimately lead to a close down. Further, considering the context of globalization and, enabling African entrepreneurs to compete favorably globally, Nwajiuba, Igwe, Binuomote, Nwajiuba, and Nwekpa, (2020) suggest for some reforms like import and export regulations which may help the local entrepreneurs to reduce the high competition in the market and, to help sustain their enterprises. 


\section{Conclusion and Recommendations}

Based on the findings, this study concludes that a gender difference in graduates' attitudes towards entrepreneurship is significant. It highlights that female graduates have higher difference in the attitudes towards entrepreneurship as compared to the influence of male graduates. The top three significant attitudinal factors towards entrepreneurship determined were entrepreneurship results in economic growth of a country, entrepreneurship results in employability and income generation and, entrepreneurship improves of individual and social growth. These top three attitudinal factors were the same for the male and female graduates despite of their ranking and importance. No gender difference in the constraints in entrepreneurship indicated that male and female graduates face the same constraints in entrepreneurship. The top three constraints faced by the male and female graduates in entrepreneurship were lack of land, lack of proper infrastructure and, lack of capital. Only three constraints in entrepreneurship namely lack of land, high competition in market and, lack of capital were determined as the significant predictors of the graduates' attitudes towards entrepreneurship. Furthermore, lack of land was the most outstanding predictor of the graduates' attitudes towards entrepreneurship followed by the high competition in market and, the lack of capital. It is recommended that these three factors be made priorities by the policy makers while making policies for entrepreneurship development in the country. A further study is also recommended to explore the perceptions of agriculture graduates on the possible strategies on how to improve on the three predicting constraints: lack of land, high competition in market and, lack of capital. A similar study can be conducted to explore more constraints predicting graduates' attitude towards entrepreneurship. There may be reasons for more inclination of female graduates towards entrepreneurship as compared to the male graduates. Therefore, a further study is needed to explore reasons for more inclination of female graduates towards entrepreneurship.

\section{References}

Abor, J., \& Quartey, P. (2010). Issues in SME development in Ghana and South Africa. International Research Journal of Finance and Economics 39, 218-228.

Abubakar, H. A. (2015). Entrepreneurship development and financial literacy in Africa. World Journal of Entrepreneurship, Management and Sustainable Development, 11(4), 281-294. https://doi.org/10.1108/WJEMSD-04-2015-0020

African Economic Research Consortium (AERC, 2014). "Youth Employment: Opportunities and Challenges", 40th Plenary Session of the AERC's Biannual Research Workshop, Lusaka, Zambia (November, 30th). http://aercafrica.org/index.php/news-events/212-aerc-biannual-workshop-climate-change-ndeconomicdevelopment-2 (Accessed: 06/01/2015).

Ahang, M. (2014). The Impact of gender inequality on economic growth in developed countries. The Accounting and Economics and Financial Management Conference, 26-27, October 2014-Terhan, Iran.

Ajzen, I. (1991). The theory of planned behavior. Organizational Behavior and Human Decision Processes, 50,179-211. https://doi.org/10.1016/0749-5978(91)90020-T

Akbari, R., Movahedi, R., \& Kochekian, H. (2011). Examining Attitude of Agricultural Students towards Employment in Agricultural Sector (Case Study: Bu-Ali Sina University). Journal of Agricultural Extension and Education Research, 2(4), 91-102.

Akinyoade, A., Dietz, T. \& Uche, C. (2017). Introduction. In Akinyoade, A., Dietz, T. \& Uche (Eds.) Entrepreneurship in Africa. Boston: Brill. https://doi.org/10.1163/9789004351615

Alain, F., Benoit, G., \& ClercNarjisse, L. (2006). Effect and Counter-effect of Entrepreneurship Education and Social Context on Student's Intentions. Estudios de Economía Aplicada, 24(2), 509-523.

Audretsch, D. B., \& Belitski, M. (2017). Entrepreneurial ecosystems in cities: Establishing the framework conditions. Journal of Technology Transfer, 42(5), 1030-1051. https://doi.org/10.1007/s10961-016-9473-8

Ali, A., Keith, J., Topping, K.J., \& Tariq, R.H. (2011). Entrepreneurial Attitudes among Potential Entrepreneurs. Pakistan Journal of Commerce and Social Science, 5(1), 12-46. http://hdl.handle.net/10419/188013

Amiri, A., \& Moradi, Y. (2009). The Survey of Entrepreneurial Attitudes Barriers of Students. Quarterly Journal of Research and Planning in Higher Education, 14(3), 45-67. http://journal.irphe.ac.ir/article-1-295-en.html 
Amungo E. (2020) Postscript: Sustaining the Growth of Private Sector in Africa. In: The Rise of the African Multinational Enterprise (AMNE), 263-275. Management for Professionals. Springer, Cham. https://doi.org/10.1007/978-3-030-33096-5_13

Arranz, N., Arroyabe, M. F., \& Fdez. de Arroyabe, J. C. (2019). Entrepreneurial intention and obstacles of undergraduate students: the case of the universities of Andalusia. Studies in Higher Education, 44(11), 2011-2024. https://doi.org/10.1080/03075079.2018.1486812

Bandiera, O. \& Natraj, A. (2013). Does gender inequality hinder development and economic growth? Evidence and Policy Implications. Washington DC: World Bank. https://doi.org/10.1596/1813-9450-6369

Barani, S., Athari, Z., \& Zarafshni, K. (2009). Survey of Agricultural Scientific-Applied Student Tendency to Entrepreneurship (Case Study: Kermanshah Province). Journal of Entrepreneurship Development, 2(6), 73-95.

Bogale, M. P. (2014). Curbing Unemployment in Africa (Botswana) by Incorporating Entrepreneurship Training in the Education System. African Perspectives.

Bosma, N. \& Levie, J. (2009). The Global Entrepreneurship Monitor global report. University Desarrollo, Santiago, Chile.

Bowen, M., Morara, M., \& Mureithi, M. (2009). Management of business challenges among small and micro enterprises in Nairobi, Kenya. KCA Journal of Business Management, 2(1), 16-31. https://doi.org/10.4314/kjbm.v2i1.44408

Brixiová, Z., Kangoye, T., \& Tregenna, F. (2020). Enterprising women in Southern Africa: When does land ownership matter?. Journal of Family and Economic Issues, 41(1), 37-51. https://doi.org/10.1007/s10834-020-09663-2

Brixiová, Z., Ncube, N., \& Bicaba, Z., (2015). Skills and Youth Entrepreneurship in Africa: Analysis with Evidence from Swaziland. World Development, 67(C), 11-26. ～https://doi.org/10.1016/j.worlddev.2014.09.027

Brush, C., Edelman, L.F., Manolova, T. \& Welter, F.(2019). A gendered look at entrepreneurship ecosystems. Small Business Economics, 53(2), 393-408. https://doi.org/10.1007/s11187-018-9992-9

Chua, J. H, Chrisman, J. J., Kellermanns, F. W., \& Wu, Z. (2011). Family involvement and new venture debt financing. Journal of Business Venture, 26(4), 472-488. https://doi.org/10.1016/j.jbusvent.2009.11.002

Chigunta, F. (2017). Entrepreneurship as a possible solution to youth unemployment in Africa. Laboring and learning, 433-451. https://doi.org/10.1007/978-981-287-032-2_19

Creswell, J. W., \& Creswell, J. D. (2017). Research design: Qualitative, quantitative, and mixed methods approaches. Sage Publications.

Cuberes, D., \& Teignier-Baque, M. (2011). Gender inequality and economic growth. Washington DC: World Bank.

Dawson, C., Henley, A., \& Latreille, P. (2009). Why do individuals choose self-employment? IZA Discussion Paper, No. 3974. Available at: http://ftp.iza.org/dp3974.pdf.

Delmar, F. \& Davidsson, P. (2000). Where do they come from? Prevalence and characteristics of nascent entrepreneurs. Entrepreneurship and Regional Development, 12, 1-23. Accessed from http://eprints.qut.edu.au https://doi.org/10.1080/089856200283063

Dembek, K., Singh, P., \& Bhakoo, V. (2016). Literature review of shared value: A theoretical concept or a management buzzword? Journal of Business Ethics, 137(2), 231-267. http://link.springer.com/10.1007/s10551-015-2554-z https://doi.org/10.1007/s10551-015-2554-z

Demiral, O. (2016). Factors Affecting Individual Attitudes and Perceptions towards Entrepreneurship: Does Education Really Matter? International Journal of Business Administration, 7(4), 43-54. http://doi.org/10.5430/ijba.v7n4p43

Díaz-García, M. C., \& Jiménez-Moreno, J. (2010). Entrepreneurial intention: the role of gender. International Entrepreneurship and Management Journal, 6(3), 261-283. https://doi.org/10.1007/s11365-008-0103-2

Dionco-Adetayo, E. A. (2006). Factors influencing attitude of youth towards entrepreneurship. International Journal of Adolescence and Youth, 13(1-2), 127-145. https://doi.org/10.1080/02673843.2006.9747970 
Diraditsile, K., \& Ontetse, M. A. (2017). Lived Experiences and Consequences of Unemployment on Women: An Emprirical study of Unemployed Young Women in Mahalapye, Botswana. Journal of International Women's Studies, 18(4), 131-143. http://vc.bridgew.edu/jiws/vol18/iss4/10

Du Toit, A. \& Gaotlhobogwe, M. (2018) A Neglected Opportunity: Entrepreneurship Education in the Lower High School Curricula for Technology in South Africa and Botswana. African Journal of Research in Mathematics, Science and Technology Education, 22(1), 37-47. https://doi.org/10.1080/18117295.2017.1420007

Engle, R. L., Dimitriadi, N., Gavidia, J. V., Schlaegel, C., Delanoe, S., Alvarado, I., He, X., Buame, S., \& Wollf, B. (2010). Entrepreneurial intent: A twelve-country evaluation of Ajzen's model of planned behavior. International Journal of Entrepreneurial Behavior and Research, 16(1), 33-57. https://doi.org/10.1108/13552551011020063

Esiobu, N. S., \& Ibe, G. O. G. (2015). Analysis of entrepreneurship development in agriculture among arable crop farmers in Imo State, Nigeria. International Journal of African and Asian Studies, 7(3), 92-99.

Faal, M. L. (2020). Understanding binding Constraints to small and medium Enterprises (SMEs) in The Gambia: A Critical Review. Asian Journal of Management, 11(2), 216-221.

Farashah, A. D. (2013). The process of impact of entrepreneurship education and training on entrepreneurship perception and intention. Study of educational system of Iran, Education and Training, 55(8/9), 868-885. https://doi.org/10.1108/ET-04-2013-0053

Fishbein, M., \& Raven, B. H. (1962). The AB scales: An operational definition of belief and attitude. Human Relations, 15(1), 35-44. https://doi.org/10.1177/001872676201500104

Fragoso, R., Rocha-Junior, W., \& Xavier, A. (2020). Determinant factors of entrepreneurial intention among university students in Brazil and Portugal. Journal of Small Business \& Entrepreneurship, 32(1), 33-57. https://doi.org/10.1080/08276331.2018.1551459

G20 Leaders' Communiqué Brisbane Summit, 15-16 November 2014, available At http://www.mofa.go.jp/mofaj/files/000059841.pdf. Accessed 18 June 2016.

Global Entrepreneurship Monitor (GEN). (2013). Global report: fifteen years of assessing entrepreneurship across the globe.

GEM (2014). Africa's Young Entrepreneurs: Unlocking the Potential for a better future'. Global Entrepreneurship Monitor UK. United Kingdom Monitoring Report. file:///H:/Downloads/1425737316GEM_UK_2014_final.pdf Accessed Nov. 25, 2017

GEM (2017-2018). Global Report. file:///C:/Users/SurfBook/Downloads/rev-gem-2017-2018-global-reportrevised-1527266790-1548584425-1549359513.pdf

Joshi, A., Kale, S., Chandel, S., \& Pal, D. K. (2015). Likert scale: Explored and explained. Current Journal of Applied Science and Technology, 396-403. https://doi.org/10.9734/BJAST/2015/14975

Monitor, G. E. (2013). Global report: fifteen years of assessing entrepreneurship across the globe. Prepared by José Ernesto Amorós and Niels Bosma.

Guerrero, M., Rialp, J., \& Urbano, D. (2008). The impact of desirability and feasibility on entrepreneurial intentions: A structural equation model. The International Entrepreneurship and Management Journal, 4(1), 35-50. https://doi.org/10.1007/s11365-006-0032-x

Haselip, J., Desgain, D., \& Mackenzie, G. (2015). Non-financial constraints to scaling-up small and medium-sized energy enterprises: findings from field research in Ghana, Senegal, Tanzania and Zambia. Energy Research \& Social Science, 5, 78-89. https://doi.org/10.1016/j.erss.2014.12.016

Haus, I., Steinmetz, H., Isidor, R., \& Kabst, R. (2013). Gender effects on entrepreneurial intention: A meta-analytical structural equation model. International Journal of Gender and Entrepreneurship, 5(2), 130- 156. https://doi.org/10.1108/17566261311328828.

Ibrahim, O. A., Devesh, S., \& Ubaidullah, V. (2017). Implication of attitude of graduate students in Oman towards entrepreneurship: an empirical study. Journal of Global Entrepreneurship Research, 7(1), 8. https://doi.org/10.1186/s40497-017-0066 
Igwe, P. A., Ogundana, A. N. A. O. M., Egere, O. M., \& Anigbo, J. A. (2018). Factors affecting the investment climate, SMEs productivity and entrepreneurship in Nigeria. European Journal of Sustainable Development, 7(1), 182-200. https://doi.org/10.14207/ejsd.2018.v7n1p182

Jaisawal, A., \& Patel, M. M. (2016). Entrepreneurial behaviour of rural women. Indian Research Journal of Extension Education, 12(1), 55-59.

Jauch, H. (2011). 'Time to Turn the Tide: Tackling Poverty, Inequality and Unemployment in Southern Africa'. Friedrich Ebert Stiftung Perspective (June).

Jelilov, G., \& Onder, E. (2016). Entrepreneurship: Issues and Solutions Evidence From Nigeria. Pyrex Journal of Business and Finance Management Research, 2(3), 010-013.

Jelonek, D., Dunay, A., Alint, B., \& Csaba, I. (2017). Academic e-learning management with e-learning scorecard. Polish Journal of Management Studies, 16(2), 122-132. https://doi.org/10.17512/pjms.2017.16.2.11

Karanassios, N. M., \& Pazarskis, S. (2006). EU strategies to encourage youth entrepreneurship: Evidence from higher education in Greece. Industry \& Higher Education, 20(1), 43-50. https://doi.org/10.5367/000000006776150747

Kew, J. (2015). Africa's young entrepreneurs: Unlocking the potential for a brighter future. Cape Town: Rothko.

Raman, K., Anantharaman, R. N., \& Ramanathan, S. (2013). Environmental, personality and motivational factors: A comparison study between women entrepreneurs and women non entrepreneurs in Malaysia. International journal of business and management, 8(13), 15. https://doi.org/10.5539/ijbm.v8n13p15

Kidane, A., \& Harvey, B. H. (2009). Profile of Entrepreneurs: employing stepwise regression analysis to determine the factors that impact the success of entrepreneurs. Review Business Research, 9(3), 55-65.

Kirchhoff, B. A., Linton, J. D., \& Walsh, S. T. (2013). Neo-Marshallian equilibrium versus Schumpeterian creative destruction: its impact on business research and economic policy. Journal of Small Business Management, 51(2), 159-166. https://doi.org/10.1111/jsbm.12018

Kleinke, C. L. (1984). Two models for conceptualizing attitude-behaviour relationship. Human Relations, 37(4), 333-350. https://doi.org/10.1177/001872678403700404

Kozina, F. L., \& Ponikvar, N. (2015). Financial literacy of first-year university students: The role of education. International Journal of Management, Knowledge and Learning, 4(2), 241-255.

Lanero, A., Vázquez, J. L., Gutiérrez, P., \& García, M. P. (2011). The impact of entrepreneurship education in European universities: an intention-based approach analyzed in the Spanish area. International Review of Public Nonprofit Marketing, 8(2), 111-130. https://doi.org/10.1007/s12208-011-0067-8

Legas, H. (2015). Challenges to entrepreneurial success in sub-Saharan Africa: A comparative perspective. European Journal of Business and Management, 7(11), 23-35.

Mahadea, D., \& Khumalo, S. (2020). Understanding the Internal and External Constraints to Growth of Microenterprise Entrepreneurship in a South African Provincial Context: A Case of Mpumalanga-Mkhondo. Journal of Developmental Entrepreneurship, 25(02), 2050013. https://doi.org/10.1142/S1084946720500132

Malema, B. W. (2011). Unemployment and the attribute of the Unemployed in Botswana. Botswana Notes and Records, 46, 58-71.

Matandare, M. A. (2018). Botswana Unemployment Rate Trends by Gender: Relative Analysis with Upper Middle Income Southern African Countries (2000-2016). Dutch Journal of Finance and Management, 2(2), 04. https://doi.org/10.20897/djfm/3837

Meyer, N., Meyer, D. F., \& Molefe, K. N. (2016). Barriers to small informal business development and entrepreneurship: the case of the Emfuleni region. Polish Journal of Management Studies, 13(1), 121-133. https://doi.org/10.17512/pjms.2016.13.1.12

Millán, J. M., Congregado, E., \& Román, C. (2014). Persistence in entrepreneurship and its implications for the European entrepreneurial promotion policy. Journal of Policy Modeling, 36(1), 83-106. https://doi.org/10.1016/j.jpolmod.2013.10.001 
Mishra, A., Igwe, P.A., Lean, J. \& Megicks, P. (2014). Supporting micro and small enterprises. In: The Routledge companion to financial services marketing. Routledge Companions in Business, Management and Accounting, 28(44). Routledge, London, 1-576. https://doi.org/10.4324/9780203517390

Movahedi, R., \& Fathi, H. (2011). Assessing agricultural students' attitude towards entrepreneurship. International Journal of Agriculture: Research and Review, 1(4), 168-173. http://ecisi.com/.../168-173.pdf

Movahedi, R., Latifi, S., \& Sayyar, L. Z. (2013). The Factors Affecting Agricultural Students' Attitude towards Self-Employment and Entrepreneurship. International Journal of Agriculture and Crop Sciences, 5(16), 1813-1819. http://ijagcs.com/.../1813-1819.pdf

Mukherjee, P., \& Mukhopadhyay, I. (2013). Impact of gender inequality on economic growth: A study developing countries. Journal of Humanities and Social Sciences, 13(2), 61-19. https://doi.org/10.9790/0837-1326169

Nafukko, F. M., \& Helen Muyia, M. A. (2010). Entrepreneurship and socioeconomic development in Africa: a reality or myth? Journal of European Industrial training, 34(2), 96-109. https://doi.org/10.1108/03090591011023961

Ncube, M., Shimeles, A., \& Verdier-Chouchane, A. (2014). 'South Africa's Quest for Inclusive Development'. In D.M. Malone, R. Kanbur, R. Medhora, and B. Currie-Alder (Eds), International Development: Ideas, Experience and Prospects. Oxford: Oxford https://doi.org/10.1093/acprof:oso/9780199671656.003.0042

Nowiński, W., Haddoud, M. Y., Lančarič, D., Egerová, D., \& Czeglédi, C. (2019). The impact of entrepreneurship education, entrepreneurial self-efficacy and gender on entrepreneurial intentions of university students in the Visegrad countries. Studies in Higher Education, $361-379$. https://doi.org/10.1080/03075079.2017.1365359

Nwajiuba, C. A., Igwe, P. A, Binuomote, M. O., Nwajiuba, A. O., \& Nwekpa, K. C. (2020). The Barriers to High-Growth Enterprises: What Do Businesses in Africa Experience? European Journal of Sustainable Development, 9(1). https://doi.org/10.14207/ejsd.2020.v9n1p317

Nwokorie, Edwin Chigozie, Adiukwu, Ikenna Kingsley (2020). Hospitality and Tourism Entrepreneurship: Administrative Barriers in Imo State, Nigeria. Turizam, 24(1), 13-32. https://doi.org/10.5937/turizam24-22955

Nybakk, E., \& Hansen, E. (2008). Entrepreneurial attitude, innovation and performance among Norwegian nature-based tourism enterprise. Forestry Policy and Economics, 10(7/8), 473-479. https://doi.org/10.1016/j.forpol.2008.04.004

Obembe, E., Otesile, O., \& Ukpong, I. (2014). Understanding the students' perspectives towards entrepreneurship. Procedia-Social and Behavioral Sciences, 145, 5-11. https://doi.org/10.1016/j.sbspro.2014.06.005

OECD. (2001). Putting the young in business: Policy challenges for youth entrepreneurship. Paris: The LEED Programme. https://doi.org/10.1787/9789264188648-en

Pauceanu, A. M., Alpenididze, O., Edu, T., \& Zaharia, R. M. (2019). What determinants influence students to start their own business? Empirical evidence from United Arab Emirates Universities. Sustainability, 11(1), 92. https://doi.org/10.3390/su11010092

Phillips, M., Moos, M., \& Nieman, G. (2014). The Impact of Government Support Initiatives on the Growth of Female Businesses in Tshwane South Africa. Mediterranean Journal of Social Sciences, 5(15), 85-92. https://doi.org/10.5901/mjss.2014.v5n15p85

Pietrobelli, C., Rabellotti, R. \& Aquilina, M. (2004) An Empirical Study of the Determinants of Self-employment in Developing Countries. Journal of International Development, 16(6), 803-820. https://doi.org/10.1002/jid.1117

Ramawati, Y., \& Rohman, F. (2020, April). The Effect of Perceived Desirability on the New Venture Creation Intention Through Entrepreneurial Motivation as Intervening Variables with Financial Capital as Moderation (Study in North Kalimantan-Border Malaysia). In 3rd Asia Pacific International Conference of Management and Business Science (AICMBS 2019), 11-326. Atlantis Press. https://doi.org/10.2991/aebmr.k.200410.048

Rivera-Santos, M., Holt, D., Littlewood, D., \& Kolk, A. (2015). Social entrepreneurship in sub-Saharan Africa. Academy of Management Perspectives, 29(1), 72-91. https://doi.org/10.5465/amp.2013.0128 
Santos, F. J., Roomi, M.A. \& Liñán, F. (2016). About gender differences and the social environment in the development of entrepreneurial intentions. Journal of Small Business Management, 54(1), 49-66. https://doi.org/10.1111/jsbm.12129

Shantz, A. S., Kistruck, G., \& Zietsma, C. (2018). The opportunity not taken: The occupational identity of entrepreneurs in contexts of poverty. Journal of Business Venturing, 33(4), 416-437. https://doi.org/10.1016/j.jbusvent.2018.02.003

Shirokova, G., Osiyevskyy, O., \& Bogatyreva, K. (2016). Exploring the intention-behavior link in student entrepreneurship: Moderating effects of individual and environmental characteristics. European Management Journal, 34(4), 386-399. https://doi.org/10.1016/j.emj.2015.12.007.

Sitaridis, I., \& Kitsios, F. (2019). Entrepreneurship as a career option for information technology students: Critical barriers and the role of motivation. Journal of the Knowledge Economy, 10(3), 1133-1167. https://doi.org/10.1007/s13132-018-0519-z.

Stafford, E. R., \& Hartman, C. L. (2014). "NGO-initiated sustainable entrepreneurship and social partnership: Greenpeace's "Solutions" campaign for natural refrigerants in North America," in Seitanidi, M. M. \& Crane, A. (Eds.) Social Partnerships and Responsible Business: A research handbook. London: Routledge.

Staniewski, M., \& Awruk, K. (2015) Motivating factors and barriers in the commencement of one's own business for potential entrepreneurs. Economic Research-Ekonomska Istraživanja, 28(1), 583-592. https://doi.org/10.1080/1331677X.2015.1083876

Tambunan, T. T. H. (2017). Women entrepreneurs in MSEs in Indonesia: Their motivations and main constraints. JWEE, (1-2), 56-86. https://doi.org/10.15640/ijgws.v5n1a9

Tchamyou, V. S. (2017). The role of knowledge economy in African business. Journal of the Knowledge Economy, 8(4), 1189-1228. https://doi.org/10.1007/s13132-016-0417-1

Teixeira, A. A., \& Davey, T. (2010). Attitudes of higher education students to new venture creation: The relevance of competencies and contextual factors. Industry and Higher Education, 24(5), 323-341. https://doi.org/10.5367/ihe.2010.0005

Terjesen, S. A., \& Lloyd, A. (2015). The 2015 female entrepreneurship index. Kelley School of Business Research Paper, 15-51. https://doi.org/10.2139/ssrn.2625254

Vamvaka, V., Stoforos, C., \& Palaskas, T. (2020). Attitude toward entrepreneurship, perceived behavioral control, and entrepreneurial intention: dimensionality, structural relationships, and gender differences. Journal of Innovative Entrepreneur, 9(5). https://doi.org/10.1186/s13731-020-0112-0

Van der Have, R. P., \& Rubalcaba, L. (2016). Social innovation research: An emerging area of innovation studies? Research Policy, 45(9), 1923-1935. https://doi.org/10.1016/j.respol.2016.06.010

Verheul, I., Thurik, R., Grilo, I., \& van der Zwan, P. (2012). Explaining preferences and actual involvement in self-employment: gender and the entrepreneurial personality. Journal of Economic Psychology, 33(2), 325-341. https://doi.org/10.1016/j.joep.2011.02.009

Wasilczlik, J. \& Zieba, K. (2008). Female entrepreneurship in transitional economies: the case of Poland. Journal of Small Business and Entrepreneurship, 21(2) 153-170. https://doi.org/10.1080/08276331.2008.10593419

World Bank. (2017). 2017 List of Low, Lower Middle and Upper Middle Income Economies. 38th Annual Conference of International Society of Clinical Biostatistics. ILO, Geneva.

World Bank. (2015). World Development Indicators (WDI). Washington, DC: World Bank Publications.

World Economic Forum. (2016). The Global Competitiveness Report 2015-2016. Availableat http://www3.weforum.org/docs/gcr/20152016/Global_Competitiveness_Report_2015-2016.pdf. Accessed 21 November 2018.

Zampetakis, L. A., Bakatsaki, M., Litos, C., Kafetsios, K. G., \& Moustakis, V. (2017). Gender-based differential item functioning in the application of the theory of planned behavior for the study of entrepreneurial intentions. Frontiers in Psychology, 8, 451. https://doi.org/10.3389/fpsyg.2017.00451.

Zellweger, T., Sieger, P., \& Halter, F. (2011). Should I stay or should I go? Career choice intentions of students with family business background. Journal of Business Venturing, 26(5), 521-536. https://doi.org/10.1016/j.jbusvent.2010.04.001 